\title{
Antioxidant and a-glucosidase inhibition activity of seaweed extracts
}

\author{
Jin-Hak Kim, Hye-Min Kang, Shin-Ho Lee, Ju-Young Lee, La-Young Park* \\ Department of Food Science and Technology, Catholic University of Daegu, Gyeongsan 712-702, Korea
}

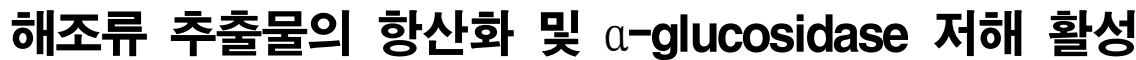

\author{
김진학 · 강혜민 · 이신호 · 이주영 · 박나영* \\ 대구가톨릭대학교 식품공학전공
}

\begin{abstract}
The antioxidant and a-glucosidase inhibition activities of 10 kinds of seaweeds Ecklonia cava (EC), Ecklonia stolonifera (ES), Eisenia bicyclis (EB), Capsosiphon fulvescens (CF), Sargassum fulvellum (SF), Undaria pinnatifida (UP), Sargassum thunbergii (ST), Codium fragile (CFr), Hizikia fusiformis (HF), and Enteromorpha prolifera (EP) were investigated. Among all the tested seaweed extracts, the total polyphenol and flavonoid contents of the EB extract were highest $150.81 \mathrm{mg} / \mathrm{g}$ and $77.02 \mathrm{mg} / \mathrm{g}$, respectively. The DPPH and ABTS radical scavenging abilities of the EB ethanol extract $(1 \mathrm{mg} / \mathrm{mL})$ were $86.26 \%$ and $99.71 \%$, respectively, and its SOD-like activity and reducing power were $21.34 \%$ and $1.710\left(\mathrm{OD}_{700}\right)$. The a-glucosidase inhibition activities of the EC, EB, and ST were above $98 \%$ at the $0.1 \mathrm{mg} / \mathrm{mL}$ concentration. These results suggest that seaweed extracts effectively prevent the what of antioxidants and decrease the blood glucose level, and may be used to develop various functional products.
\end{abstract}

Key words : seaweed extract, antioxidant, a-glucosidase, physiological functionalities

\section{서 론}

최근 경제가 발전함에 따라 평균수명이 증가하면서 퇴행 성 질환과 관련된 문제가 야기되고 있으며(1), 이러한 퇴행 성 질환은 Superoxide anion $\operatorname{radical}\left(\mathrm{O}^{2-}\right)$, hydroxyl $(\cdot \mathrm{OH})$, singlet oxygen $\left(1 \mathrm{O}^{2}\right)$ 및 hydrogen peroxide $\left(\mathrm{H}_{2} \mathrm{O}_{2}\right)$ 등 활성산 소종이 체내에서 소거되지 않기 때문인 것으로 밝혀지면서 이를 제거하는 항산화제에 관한 연구가 끊임없이 진행되고 있다(2). 또한 항산화 작용과 당뇨병은 밀접한 연관이 있으 며(3), 당뇨병이 진행되는 동안 베타세포의 기능 손상에 의해 체내 free radical의 농도와 산화적 스트레스가 증가되 며, 항산화 효소의 활성을 감소시켜 합병증을 유발하게 된 다(4). 따라서 당뇨병의 산화적 손상을 줄일 수 있는 항산화 계의 강화는 체내 free radical과 지질 과산화물의 증가로

*Corresponding author. E-mail : violet74@cu.ac.kr

Phone : 82-53-850-3217, Fax : 82-53-850-3217

Received 26 December 2014; Revised 9 April 2015; Accepted 13 April 2015.

Copyright (C) The Korean Society of Food Preservation. All rights reserved.
인해 발생되는 다양한 합병증 발생 예방 및 치료에 매우 중요하다(5). 현재 butylated hydroxyanisole(BHA) 및 butylated hydroxytoluene(BHT)는 강력한 합성 항산화제로 알려졌지만, 일정 수준 이상 섭취 시 안전성과 유해성 문제 가 제기되고 있으며(6), 제 2형 당뇨병 치료제로 사용되는 a-glucosidase 저해제 중 acarbose, volglibose 등은 장시간 복용시 복부팽만감, 구토, 설사 등의 부작용을 나타내어 그 사용이 제한적이다(7). 이러한 부작용을 줄이고 항산화 및 항당뇨 활성을 가지는 새로운 기능성 소재를 천연물로부 터 발굴하기 위한 연구는 매우 필요하다.

우리나라는 삼면이 바다로 둘러싸여 다양한 해산물들을 쉽게 얻을 수 있으며, 특히 김, 미역, 다시마 등 다양한 해조 류는 건제품, 염장품 및 조미품 등의 유용 식용자원으로 이용되어 왔으며(8), 최근 해조류의 중금속 제거 활성(9), 항산화 활성(10), 항암활성(11), 항균 활성(12) 등 다양한 생리활성이 보고되어 환, 정, 드링크 등의 다양한 건강기능 식품이 출시되고 있다. 지구 표면적의 $70 \%$ 를 차지하는 해 양에는 지구 생물 종의 $80 \%$ 이상이 서식하고 있으며, 다양 한 해양 생물들은 육상생물과는 전혀 다른 생활환경으로 인해 특이한 생리활성물질을 보유하고 있다 $(13,14)$. 따라서 
광범위한 해양생물자원의 유용 생리활성 평가에 따른 생물 소재 개발 연구가 지속적으로 필요하며, 특히 한국의 경우 세계 4위의 생산량을 가지는 해조류(13)에 대한 보다 적극 적인 생리활성 연구 및 산업적 이용 연구가 필요하다. 본 연구에서는 해양생물 유래 천연 기능성 소재 개발 연구의 일환으로 추출 용매를 달리한 국내산 주요 해조류 추출물의 항산화 및 $a$-glucosidase 저해 활성을 조사하였다.

\section{재료 및 방법}

\section{재료 및 전처리}

실험재료는 국내 연안에 자생하는 해조류 중 식용이 가 능한 감태(Ecklonia cava), 곰피(Ecklonia stolonifera), 대황 (Eisenia bicyclis), 매생이(Capsosiphon fulvescens), 모자반 (Sargassum fulvellum), 미역(Undaria pinnatifida), 지충이 (Sargassum thunbergii), 청각(Codium fragile), 톳(Hizikia fusiformis), 파래(Enteromorpha prolifera)를 사용하였다. 해 조류는 울릉도, 제주도 등 각각의 산지로부터 구매하여 흐 르는 물로 여러 번 세척하여 염분을 제거한 뒤 $60^{\circ} \mathrm{C}$ 에서 12 시간 동안 열풍건조하였으며, 건조한 시료는 분쇄기 (IKA® A11 basic, IKA® Werke GmbH \& Co., KG, Staufen, Germany)를 이용하여 40 mesh 이하로 분쇄한 후 추출물 제조에 사용하였다.

\section{해조류 추출물의 제조}

10 종의 해조류 분말을 물과 에탄올을 용매로 하여 추출 물을 제조하였다. 열수 추출은 각각의 해조류 $20 \mathrm{~g}$ 에 증류수 $1 \mathrm{~L}$ 를 첨가하여 $121^{\circ} \mathrm{C}$ 에서 15 분간 열수추출하였고, 에탄올 추출은 해조류 $20 \mathrm{~g}$ 에 에탄올 $1 \mathrm{~L}$ 를 첨가하여 하루 동안 $200 \mathrm{rpm}$ 에서 교반하여 추출하였다. 열수추출물과 에탄올 추출물은 원심분리(Centrige 5810R, Effendorf, Hmburg, Germany) 후 여과하여 vacuum evaporator(WB2000, Heidolph, Schwabach, Germany)에서 농축하였고, 일정한 양을 각각의 추출용매에 녹여 항산화 및 a-glucosidase 저해 활성 측정에 사용하였다.

\section{총 폴리페놀 및 총 플라보노이드 함량 측정}

총 폴리페놀 함량 측정은 Folin-Denis 법(15)에 따라 시료 $1 \mathrm{~mL}$ 에 $0.2 \mathrm{~N}$ Folin-Ciocalteu's phenol reagent(Sigma-Aldrich Co., St. Louis, MO, USA) $1 \mathrm{~mL}$ 를 가하여 실온에서 3분간 반응시킨 후, $7.5 \% \mathrm{Na}_{2} \mathrm{CO}_{3} 1 \mathrm{~mL}$ 을 가한 후 암소에서 1 시간 동안 방치한 후 $765 \mathrm{~nm}$ 에서 흡광도를 측정하였다. 총 폴리 페놀 함량은 garlic acid를 표준물질로 한 표준곡선에 의하 여 산출하였다.

총 플라보노이드 함량은 Abdel-Hameed(16)의 방법에 따 라 시료 $1 \mathrm{~mL}$ 에 $5 \%$ sodium nitrite $0.15 \mathrm{~mL}$ 를 가한 후 $25^{\circ} \mathrm{C}$ 에
서 6분간 방치한 다음 $10 \%$ aluminium chloride $0.3 \mathrm{~mL}$ 를 가하여 $25^{\circ} \mathrm{C}$ 에서 5 분간 방치하였다. 다음 $1 \mathrm{~N} \mathrm{NaOH} 1 \mathrm{~mL}$ 를 가하고 교반한 후 $510 \mathrm{~nm}$ 에서 흡광도를 측정하였으며, rutin hydrate(Sigma-Aldrich Co.)의 검량선에 의하여 함량을 산출하였다.

\section{DPPH radical 소거능}

$\mathrm{DPPH}$ radical 소거능의 측정은 Blois의 방법(17)을 변형 하여 시료 $0.4 \mathrm{~mL}$ 에 $0.4 \mathrm{mM} \mathrm{DPPH}(\mathrm{a}$, $a$-diphenyl- $\beta$ -picrylhydrazyl, Sigma-Aldrich Co.) 에탄올 용액 $0.8 \mathrm{~mL}$ 을 진탕 혼합하고, 10 분간 방치 후 분광광도계를 사용하여 525 $\mathrm{nm}$ 에서 흡광도를 측정하여 계산식, DPPH radical scavenging ability $(\%)=100-[(\mathrm{OD}$ of sample/OD of control $) \times 100]$ 에 의하 여 활성을 산출하였다.

\section{ABTS radical 소거능}

ABTS[2,2'-azino-bis(3-ethylbenzothiazoline-6-sulfonic acid) diammonium salt, Sigma- Aldrich Co.] radical 소거능은 ABTS radical cation decolorization assay(18)를 이용하여 측 정하였다. $7.4 \mathrm{mM}$ 의 $\mathrm{ABTS}$ 와 $2.6 \mathrm{mM}$ potassium persulfate 를 혼합하여 실온 - 암소에서 24시간 동안 방치하여 radical 을 형성시킨 다음 실험 직전에 ABTS 용액을 $732 \mathrm{~nm}$ 에서 흡광도가 $0.700 \pm 0.030$ (mean $\pm \mathrm{SD})$ 이 되도록 phosphate-buffered saline $(\mathrm{pH}$ 7.4)으로 희석하여 사용하였다. 추출물 $50 \mu \mathrm{L}$ 에 ABTS 용액 $950 \mu \mathrm{L}$ 를 첨가하여 암소에서 10 분간 반응시킨 후 $732 \mathrm{~nm}$ 에서 흡광도를 측정하여 계산식, ABTS radical scavenging ability $(\%)=100-[(\mathrm{OD}$ of sample/ OD of control $) \times 100]$ 에 의하여 활성을 산출하였다.

\section{$\mathrm{SOD}$ 유사활성 소거능}

Marklund와 Marklund(19)의 방법에 따라 각 추출물 200 $\mu \mathrm{L}$ 에 $\mathrm{pH} 8.5$ 로 조정한 tris- $\mathrm{HCl}$ buffer 용액 $3 \mathrm{~mL}$ 와 $7.2 \mathrm{mM}$ pyrogallol $200 \mu \mathrm{L}$ 를 가하고 $25^{\circ} \mathrm{C}$ 에서 10 분간 반응시킨 후 $1 \mathrm{~N} \mathrm{HCl} 1 \mathrm{~mL}$ 를 가하여 반응을 정지시키고 $420 \mathrm{~nm}$ 에서 흡광도를 측정하였으며 계산식, SOD-like activity $(\%)=$ $100-[(\mathrm{OD}$ of sample/OD of control) $\times 100]$ 에 의하여 활성을 산출하였다.

환원력

Oyaizu(20)의 방법에 따라 시료 $1 \mathrm{~mL}$ 에 $0.2 \mathrm{M}$ phosphate buffer(pH 6.6) $2.5 \mathrm{~mL}$ 와 $1 \%$ potassium ferricyanide 용액 $2.5 \mathrm{~mL}$ 를 가한 후 $50^{\circ} \mathrm{C}$ 에서 30 분간 반응시켰다. 다음 $10 \%$ trichloroacetic acid(TCA) 용액 $2.5 \mathrm{~mL}$ 를 가한 후 $1,650 \times \mathrm{g}$ 에 서 10 분간 원심분리하였으며, 상징액 $2.5 \mathrm{~mL}$ 에 증류수 2.5 $\mathrm{mL}$ 와 $0.1 \% \mathrm{FeCl}_{3}$ 용액 $0.5 \mathrm{~mL}$ 를 가한 후 $700 \mathrm{~nm}$ 에서 흡광도를 측정하였다. 


\section{지방산패억제능}

지방 산패 억제 효과는 Buege와 Aust(21)의 thiobarbituric acid reactive substances(TBARS) 방법을 변형하여 측정하였 다. 상온에서 추출물 $0.1 \mathrm{~mL}$, emulsion oil $0.5 \mathrm{~mL}$, 증류수 $0.3 \mathrm{~mL}$ 와 $\mathrm{Fe}^{2+}$ (산화촉진제) $0.1 \mathrm{~mL}$ 를 섞은 후 $37^{\circ} \mathrm{C}$ 에서 1시 간 반응시켰다. 반응 혼합물을 잘 섞은 다음 $2 \mathrm{~mL} \mathrm{TBA/TCA}$ 시약을 가하고 다시 혼합 후 끓는 물에서 15 분간 가열시켰 다. 가열 후 찬물에서 식힌 후 $3,000 \mathrm{rpm}$ 에서 10 분간 원심분 리 시킨 상등액을 $531 \mathrm{~nm}$ 에서 흡광도를 측정하였고, 공시 료는 시료 대신에 증류수를 가하여 같은 방법으로 측정하였 으며 계산식, TBARS(inhibition of lipid rancidity, $\%)=100-[(\mathrm{OD}$ of sample/OD of control $) \times 100]$ 에 의하여 활성 을 산출하였다.

\section{a-glucosidase 저해 활성}

$\mathrm{Kim}$ 등(22)의 방법에 따라 추출물 $0.05 \mathrm{~mL}, 0.2 \mathrm{unit} / \mathrm{mL}$ a-glucosidase $0.05 \mathrm{~mL}$ 와 $200 \mathrm{mM}$ potassium phosphate buffer(pH 7.0) $0.05 \mathrm{~mL}$ 를 잘혼합하여 $37^{\circ} \mathrm{C}$ 에서 10 분간 전처 리하였다. 다음에 $3 \mathrm{mM} \rho \mathrm{\rho NPG}(\rho$-nitrophenyl a-Dglucopyranoside) $0.1 \mathrm{~mL}$ 를 첨가하여 $37^{\circ} \mathrm{C}$ 에서 10 분간 반응 시킨 후 $0.1 \mathrm{M} \mathrm{Na} \mathrm{CO}_{3} 0.75 \mathrm{~mL}$ 로 반응을 정지시켜 405 $\mathrm{nm}$ 에서 흡광도를 측정하였으며, 저해활성은 아래의 식에 의해 산출하였다.

a-glucosidase inhibition activity $(\%)=\left[1-\left(\mathrm{C}_{\mathrm{Abs}}-\mathrm{S}_{\mathrm{Abs}}\right) /\left(\mathrm{C}_{\mathrm{Abs}}-\mathrm{B}_{\mathrm{Abs}}\right)\right] \times 100$

$$
\begin{aligned}
& \mathrm{C}_{\mathrm{Abs}} \text {, : 대조구 흡광도 } \\
& \mathrm{S}_{\mathrm{Abs}} \text {, 시료 흡광도 } \\
& \mathrm{B}_{\mathrm{Abs}} \text {, : 시료 무첨가구의 흡광도 }
\end{aligned}
$$

\section{통계처리}

모든 실험은 3회 반복으로 행하였으며, 평균치간의 유의 성은 SPSS(Statistical Package for Social Sciences, 19.0, SPSS Inc., Chicago, IL, USA) software를 이용, $\mathrm{p}<0.05$ 수준 으로 Duncan's multiple range test에 의하여 검정하였다.

\section{결과 및 고찰}

\section{총 폴리페놀 및 플라보노이드 함량}

국내 자생하는 대표적 해조류의 추출용매를 달리한 추출 물의 총 폴리페놀 및 플라보노이드 함량을 측정한 결과는 Table 1과 같다. 본 연구에 사용한 해조류의 총 폴리페놀 및 플라보노이드 함량은 에탄올 추출물이 물 추출물보다 더 높은 경향을 나타내었다. 총 폴리페놀 함량은 대황(EB) 열수 추출물과 에탄올 추출물이 각각 $98.75150 .81 \mathrm{mg} / \mathrm{g}$ 으 로 가장 높았으며, 감태(EC), 지충이 $(\mathrm{ST})$, 곰피 $(\mathrm{ES})$, 매생이
$(\mathrm{CF})$, 톳(HF), 파래(EP), 모자반(SF), 청각(CFr), 미역(UP) 순으로 나타났다. 이는 갈조류들이 녹조류 및 홍조류보다 폴리페놀 함량이 많다는 Ahn 등(23)의 연구 결과와 일치하 였다. 플라보노이드 함량도 대황 열수 추출물과 에탄올 추 출물이 각각 $31.77,77.02 \mathrm{mg} / \mathrm{g}$ 으로 가장 높았으며, 총 폴리 페놀 함량과 유사한 경향을 나타내었다. 항산화 물질 중 폴리페놀 화합물들은 우수한 항산화 활성을 가지는 것으로 알려져 있으며, 이는 free radical을 안정화시키는 phenolic ring이 존재하기 때문이다. 또한 플라보노이드는 주로 anthocyanidins, flavonols, flavones, cathechins 및 flavanones 등으로 구성되어 있으며, 그 구조에 따라 특정 플라보노이 드는 항산화 및 항균성 등 다양한 생리활성을 갖고 있는 것으로 보고되고 있다(24).

Table 1. Total phenolic and flavonoid contents of the extracts from 10 different seaweeds

\begin{tabular}{ccccc}
\hline \multirow{2}{*}{ Sample $^{1)}$} & \multicolumn{2}{c}{ Polyphenol contents $(\mathrm{mg} / \mathrm{g})$} & \multicolumn{2}{c}{ Flavonoid contents $(\mathrm{mg} / \mathrm{g})$} \\
\cline { 2 - 5 } & WE & EE & WE & EE \\
\hline EC & $69.46 \pm 0.43^{\mathrm{h} 2}$ & $144.69 \pm 0.43^{\mathrm{i}}$ & $16.78 \pm 0.30^{\mathrm{g}}$ & $64.79 \pm 0.18^{\mathrm{f}}$ \\
ES & $40.97 \pm 0.13^{\mathrm{g}}$ & $79.16 \pm 0.22^{\mathrm{g}}$ & $13.55 \pm 0.04^{\mathrm{f}}$ & $22.46 \pm 0.36^{\mathrm{e}}$ \\
EB & $98.75 \pm 0.65^{\mathrm{j}}$ & $150.81 \pm 0.69^{\mathrm{j}}$ & $31.77 \pm 0.26^{\mathrm{h}}$ & $77.02 \pm 0.09^{\mathrm{g}}$ \\
CF & $7.86 \pm 0.22^{\mathrm{c}}$ & $37.73 \pm 0.26^{\mathrm{f}}$ & $3.47 \pm 0.13^{\mathrm{d}}$ & $10.86 \pm 0.36^{\mathrm{b}}$ \\
SF & $14.50 \pm 0.56^{\mathrm{e}}$ & $14.28 \pm 0.17^{\mathrm{c}}$ & $1.62 \pm 0.45^{\mathrm{b}}$ & $8.89 \pm 0.54^{\mathrm{a}}$ \\
UP & $5.23 \pm 0.26^{\mathrm{a}}$ & $11.78 \pm 0.19^{\mathrm{s}}$ & $2.53 \pm 0.14^{\mathrm{c}}$ & $11.30 \pm 0.09^{\mathrm{bc}}$ \\
ST & $74.76 \pm 0.22^{\mathrm{i}}$ & $97.71 \pm 0.22^{\mathrm{h}}$ & $11.95 \pm 0.97^{\mathrm{e}}$ & $16.48 \pm 0.45^{\mathrm{d}}$ \\
CFr & $6.44 \pm 0.34^{\mathrm{b}}$ & $12.43 \pm 0.13^{\mathrm{b}}$ & $0.68 \pm 0.12^{\mathrm{a}}$ & $8.71 \pm 1.96^{\mathrm{a}}$ \\
HF & $16.44 \pm 0.26^{\mathrm{f}}$ & $19.89 \pm 0.34^{\mathrm{e}}$ & $1.24 \pm 0.13^{\mathrm{ab}}$ & $12.20 \pm 0.09^{\mathrm{c}}$ \\
EP & $8.68 \pm 0.26^{\mathrm{d}}$ & $16.61 \pm 0.17^{\mathrm{d}}$ & $1.18 \pm 0.08^{\mathrm{ab}}$ & $8.98 \pm 0.27^{\mathrm{a}}$ \\
\hline
\end{tabular}

${ }^{1)} \mathrm{EC}$, Eckonia cava; ES, Ecklonia stolonifera; EC, Eisenia bicyclis, CF, Capsosiphon fulvescens, SF, Sargassum fulvellum, UP, Undaria pinnatifida; ST, Sargassum thunbergii, $\mathrm{CFr}$, Codium fragile, $\mathrm{HF}$, Hizikia fisiformis, EP, Enteromorpha prolifera; WE, water extract; EE, ethanol extract.

${ }^{2)}$ Means with different superscripts in a column indicate significant differences $(\mathrm{p}<0.05)$.

$\mathrm{DPPH}$ 및 ABTS radical 소거능

해조류의 물 및 에탄올 추출물들 $(1 \mathrm{mg} / \mathrm{mL})$ 의 $\mathrm{DPPH}$ 및 ABTS radical 소거능 측정 결과는 Table 2 와 같다. 해조류 추출물의 DPPH radical 소거능은 총 폴리페놀 및 플라보노 이드 함량이 높은 감태, 곰피, 대황, 지충이 추출물에서 비교 적 높은 활성을 나타내었으며, 대황 열수 추출물과 에탄올 추출물이 각각 $63.36,86.26 \%$ 로 가장 높은 소거능을 나타내 었다. ABTS radical 소거능은 모든 해조류 추출물에서 활성 을 나타내었으며, 감태, 대황, 지충이 추출물은 열수와 에탄 올 추출물에서 모두 $99 \%$ 이상의 높은 활성을 나타내었으 며, 곰피 열수와 에탄올 추출물은 각각 $84.03,99.58 \%$ 를 나타내었다. 이상의 결과 해조류 추출물은 음이온 소거능 을 측정하는 DPPH radical 소거능보다 양이온 소거능을 측정하는 $\mathrm{ABTS}$ radical 소거능이 우수하였으며, 총 폴리페 
놀과 플라보노이드 함량이 비교적 높은 감태, 곰피, 대황, 지충이 추출물에서 $\mathrm{DPPH}$ 및 $\mathrm{ABTS}$ radical 소거능 역시 우수하였다. 이러한 결과는 각 추출물이 함유하고 있는 총 페놀 화합물의 함량이 증가하면서 항산화 활성도 증가한다 는 Seo 등(25)의 보고와 유사하였다.

Table 2. DPPH and ABTS radical scavenging abilities of the extracts from 10 different seaweeds

\begin{tabular}{ccccc}
\hline \multirow{2}{*}{ Sample $^{1)}$} & \multicolumn{2}{c}{$\mathrm{DPPH}^{2)}(\%)$} & \multicolumn{2}{c}{ ABTS $(\%)$} \\
\cline { 2 - 5 } & WE & EE & WE & EE \\
\hline EC & $42.05 \pm 0.40^{\mathrm{c} 3)}$ & $78.72 \pm 0.49^{\mathrm{f}}$ & $99.63 \pm 0.16^{\mathrm{e}}$ & $99.68 \pm 0.08^{\mathrm{g}}$ \\
ES & $10.77 \pm 0.72^{\mathrm{a}}$ & $42.42 \pm 0.99^{\mathrm{d}}$ & $84.03 \pm 1.99^{\mathrm{d}}$ & $99.35 \pm 0.08^{\mathrm{g}}$ \\
EB & $63.36 \pm 0.89^{\mathrm{d}}$ & $86.26 \pm 1.09^{\mathrm{g}}$ & $99.54 \pm 0.08^{\mathrm{e}}$ & $99.58 \pm 0.14^{\mathrm{g}}$ \\
CF & - & $10.37 \pm 1.82^{\mathrm{c}}$ & $22.81 \pm 1.89^{\mathrm{c}}$ & $55.68 \pm 3.33^{\mathrm{f}}$ \\
SF & - & - & $24.47 \pm 0.62^{\mathrm{b}}$ & $27.15 \pm 1.41^{\mathrm{d}}$ \\
UP & - & - & $13.20 \pm 0.52^{\mathrm{a}}$ & $18.93 \pm 0.49^{\mathrm{b}}$ \\
ST & $38.52 \pm 2.82^{\mathrm{b}}$ & $68.32 \pm 5.03^{\mathrm{e}}$ & $99.86 \pm 0.14^{\mathrm{e}}$ & $99.68 \pm 0.08^{\mathrm{g}}$ \\
CFr & - & - & $14.87 \pm 0.56^{\mathrm{a}}$ & $14.96 \pm 2.73^{\mathrm{a}}$ \\
HF & - & $5.48 \pm 2.35^{\mathrm{b}}$ & $30.89 \pm 0.97^{\mathrm{c}}$ & $38.69 \pm 0.58^{\mathrm{e}}$ \\
EP & - & $3.80 \pm 0.45^{\mathrm{a}}$ & $13.34 \pm 0.71^{\mathrm{a}}$ & $23.87 \pm 1.15^{\mathrm{c}}$ \\
\hline
\end{tabular}

${ }^{1} \mathrm{EC}$, Eckonia cava, ES, Eckonia stolonifera; EC, Eisenia bicyclis, CF, Capsosiphon fulvescens, SF, Sargassum fulvellum, UP, Undaria pinnatifida; ST, Sargassum thunbergii, CFr, Codium fragile, HF, Hizikia fusiformis, EP, Enteromorpha prolifera; WE, water extract; EE, ethanol extract.

${ }^{2} \mathrm{DPPH}$, DPPH radical scavenging ability; ABTS, ABTS radical scavenging ability.

${ }^{3}$ Means with different superscripts in a column indicate significant differences $(\mathrm{p}<0.05)$.

\section{SOD 유사활성}

용매를 달리하여 추출한 해조류 추출물 $(1 \mathrm{mg} / \mathrm{mL})$ 의 $\mathrm{SOD}$ 유사활성 측정 결과는 Fig. 1과 같이 나타났다. 해조류 열수 추출물은 $0.79 ~ 16.39 \%$ 의 범위를 나타내었으며, 대황 열수 추출물이 $16.39 \%$ 로 가장 높았다. 반면에 해조류 에탄 올 추출물은 열수 추출물에 비해 높았으며, 7.05 21.34\%의 범위를 나타내었고, 열수 추출물에서와 같이 대황 에탄올 추출물이 $21.34 \%$ 로 가장 높았다. SOD 효소는 식물이나 동물에 있어 활성산소를 제거하는 항산화 효소로 알려져 있으며, 이러한 SOD 유사활성을 갖는 항산화 물질로는 phenolic acids, flavonoids, anthocyanins 및 isoflavonoids와 같은 페놀성 화합물들이 알려져 있다 $(26,27)$.

\section{환원력}

용매를 달리하여 추출한 해조류 추출물 $(1 \mathrm{mg} / \mathrm{mL})$ 의 환 원력 측정 결과는 Fig. 2 와 같이 나타났다. 추출 용매에 따른 환원력 $\left(\mathrm{OD}_{700}\right)$ 은 열수 추출물에서 0.010 0.876 범위를 나타내었으며, 대황 열수 추출물이 0.876 으로 높은 환원력 을 나타내었고, 매생이, 모자반, 미역, 청각, 톳, 파래는 0.1 이하의 낮은 환원력을 나타내었다. 에탄올 추출물의 경우 0.060 1.710의 범위를 나타내었으며, 그 중 대황, 감태, 지충
이, 곰피 에탄올 추출물이 각각 $1.710,1.472,0.702,0.459$ 로 다른 해조류에 비해 높았다. 이상의 결과 열수 추출물에 비해 에탄올 추출물에서 환원력이 높았으며, phenol성 물질 이 항산화능을 포함한 다양한 생리적 효능을 나타내며 이는 주로 환원력에 의한 효과라고 보고한 결과(28)와 같이 환원 력이 우수한 해조류인 대황은 다양한 항산화 및 생리활성 기능성 소재로 활용될 수 있을 것으로 판단된다.

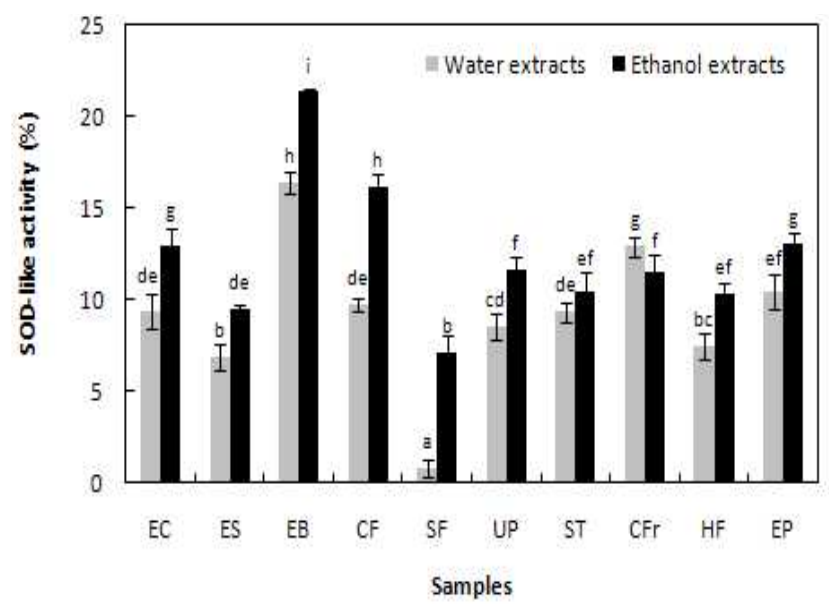

Fig. 1. SOD-like activity of the extracts $(1 \mathrm{mg} / \mathrm{mL})$ from 10 different seaweeds.

EC, Ecklonia cava; ES, Ecklonia stolonifera, EC, Eisenia bicyclis, CF, Capsosiphon fulvescens, SF, Sargassum fulvellum, UP, Undaria pinnatifida, ST, Sargassum thunbergii, $\mathrm{CFr}$, Codium fragile, HF, Hizikia fusiformis, EP, Enteromorpha prolifera; WE, water extract; EE, ethanol extract. Means with different superscripts in a bar indicate significant differences $(\mathrm{p}<0.05)$.

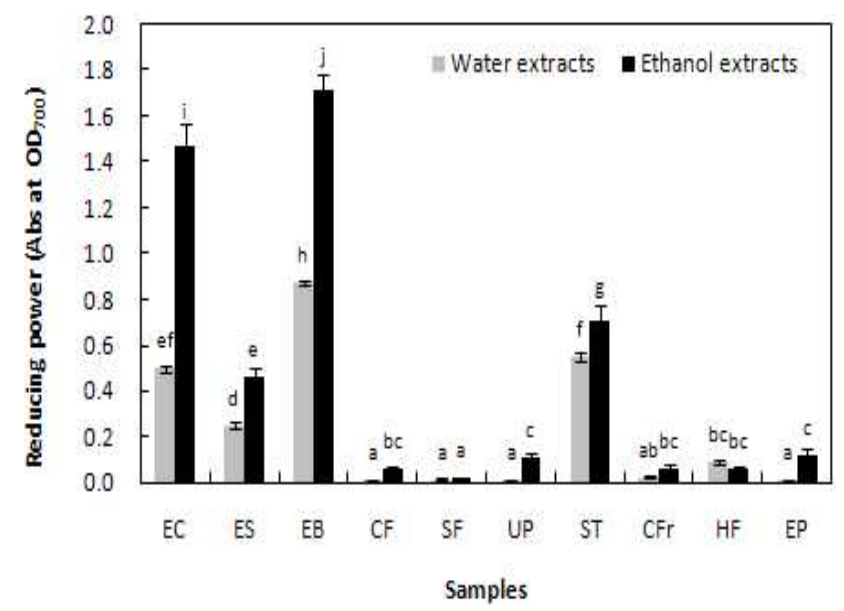

Fig. 2. Reducing power of the extracts $(1 \mathrm{mg} / \mathrm{mL})$ from 10 different seaweeds.

EC, Ecklonia cava; ES, Ecklonia stolonifera; EC, Eisenia bicyclis; CF, Capsosiphon fulvescens, SF, Sargassum fulvellum, UP, Undaria pinnatifida; ST, Sargassum thunbergii, $\mathrm{CF}$, Codium fragile, $\mathrm{HF}$, Hizikia fusiformis, EP, Enteromorpha prolifera; WE, water extract; EE, ethanol extract. Means with different superscripts in a bar indicate significant differences $(p<0.05)$.

\section{지방 산패 억제능}

생체 내에서 세포막에 존재하는 인지질 및 당지질과 혈 관에 존재하는 지질은 산소와 결합하여 과산화물을 만들고 


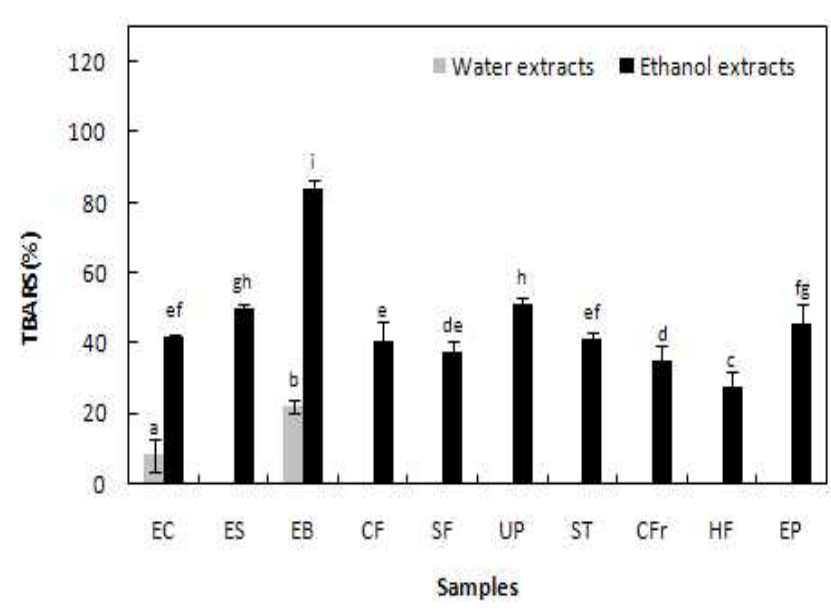

Fig. 3. TBARS of the extracts $(1 \mathrm{mg} / \mathrm{mL})$ from 10 different seaweeds.

EC, Ecklonia cava; ES, Ecklonia stolonifera, EC, Eisenia bicyclis, CF, Capsosiphon fulvescens, SF, Sargassum fulvellum, UP, Undaria pinnatifida; ST, Sargassum thunbergii, $\mathrm{CFr}$, Codium fragile, HF, Hizikia fusiformis, EP, Enteromorpha prolifera; WE, water extract; EE, ethanol extract. Means with different superscripts in a bar indicate significant differences $(\mathrm{p}<0.05)$.

이들의 연속반응에 의하여 alcohol류, aldehyde류, ketone류 등을 생성하여 생체 내에서 $\mathrm{DNA}$ 를 손상시켜 암을 유발하 기도 하며, 세포의 노화와도 관련이 있는 것으로 알려져 있다(29). 추출 용매에 따른 해조류 추출물 $(1 \mathrm{mg} / \mathrm{mL})$ 의 지 방산패억제능 측정 결과는 Fig. 4 와 같다. 해조류 열수 추출 물은 대황과 감태에서 각각 $21.82,8.21 \%$ 의 지방산패억제 능을 나타내었으며, 다른 해조류의 경우 $1 \mathrm{mg} / \mathrm{mL}$ 의 농도에 서 지방산패억제능이 나타나지 않았다. 반면에 해조류 에 탄올 추출물은 모든 시료에서 $27.60 \sim 83.95 \%$ 범위의 지방산 패억제능을 나타내었으며, 그 중 대황 에탄올 추출물이 $83.95 \%$ 로 가장 높았다.

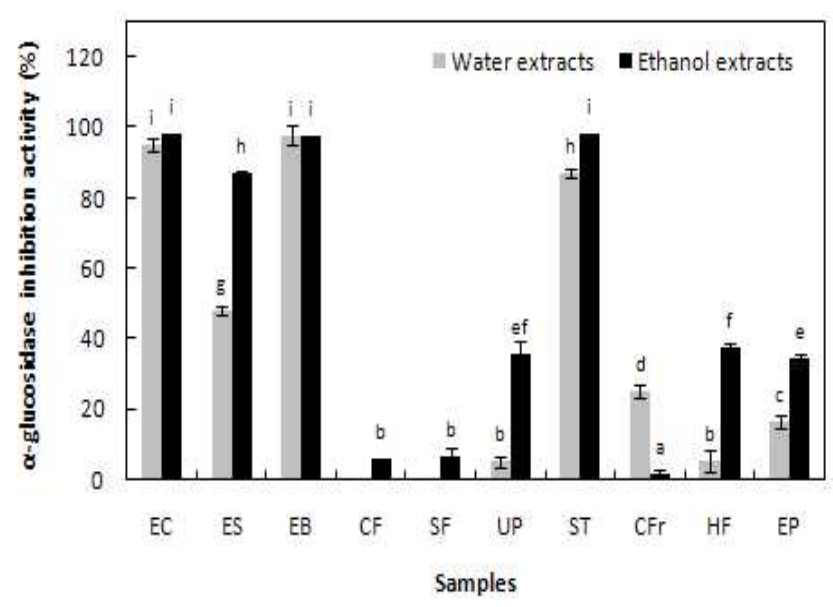

Fig. 4. a-Glucosidase inhibition activity of the extracts $(0.1 \mathrm{mg} / \mathrm{mL})$ from 10 different seaweeds.

EC, Ecklonia cava; ES, Ecklonia stolonifera; EC, Eisenia bicyclis, CF, Capsosiphon fulvescens, SF, Sargassum fulvellum, UP, Undaria pinnatifida; ST, Sargassum thunbergii, $\mathrm{CFr}$, Codium fragile, HF, Hizikia fisiformis, EP, Enteromorpha prolifera; WE, water extract; EE, ethanol extract. Means with different superscripts within a bar indicate significant differences $(\mathrm{p}<0.05)$.

\section{a-Glucosidase 저해 활성}

a-Glucosidase는 소장 상피세포의 brush-border membrane 에 존재하는 효소(30)로서 소장에서 음식물 중의 전분을 포도당과 같은 단당으로 분해하여 흡수시킨다. $a-G l u c o s i d a s e$ 저해제는 소장점막의 미세융모막에 존재하는 이당류의 분 해효소를 가역적으로 억제하여 탄수화물의 흡수를 지연시 키는 역할을 하며, 소장 전체에 포도당이 흡수되어 식후혈 당 상승을 완만하게 한다(31). 해조류 추출물의 a -glucosidase 저해 활성을 측정하여 향후 혈당상승 억제제로 활용될 수 있는 소재로서의 가능성을 검토하였다. 해조류 추출물 $(0.1 \mathrm{mg} / \mathrm{mL})$ 의 a-glucosidase 저해활성은 비교적 감 태, 곰피, 대황, 지충이 추출물에서 높게 나타내었으며, 열 수 추출물의 경우 각각 $95.17,48.07,97.75,87.13 \%$ 를 나타 내었으며, 에탄올 추출물의 경우 각각 $98.04,86.90,97.81$, $97.97 \%$ 를 나타내었다. 항산화 활성의 결과와 같이 총 폴리 페놀 함량이 높은 해조류가 a-glucosidase 저해 활성이 뛰어 난 것으로 판단되며, 이는 vanillic acid, $p$-hydroxybenzaldehyde 과 같은 phenolic acid계 및 플라보노이드계 화합물이 항산 화 효과뿐만 아니라 높은 a-glucosidase 저해활성을 나타낸 다는 보고(32)와 일치하였다. 본 연구에서 국내 자생하는 해조류를 대상으로 항산화 및 a-glucosidase 저해 활성을 비교한 결과, 대황, 감태, 지충이 등의 갈조류에 속하는 해조 류가 총 폴리페놀과 플라보노이드 함량이 많았고, 항산화 활성 및 a-glucosidase 저해 활성도 우수하였다. 따라서 생리 활성이 우수한 해조류를 원료로 사용하여 기능성 소재를 개발하고 이를 활용한 다양한 제품화 관련 추가 연구가 필요하다.

\section{요 약}

해양생물 유래 기능성 소재 개발 연구의 일환으로, 국내 자생하는 감태 외 9종(곰피, 대황, 매생이, 모자반, 미역, 지충이, 청각, 톳, 파래)의 해조류을 이용하여 열수 및 에탄 올 추출물을 제조하여 추출물의 항산화 활성 및 $a$ -glucosidase 저해활성을 조사하였다. 총 페놀 및 플라보노 이드 함량은 대황 에탄올 추출물에서 각각 $150.81,77.02$ $\mathrm{mg} / \mathrm{g}$ 으로 가장 많았다. DPPH radical 소거능은 대황, 감태, 지충이 에탄올 추출물이 각각 $86.26,78.72,68.32 \%$ 를 나타 내었으며, ABTS radical 소거능은 대황, 감태, 지충이 열수 및 에탄올 추출물에서 모두 $99 \%$ 이상의 높은 활성을 나타 내었다. SOD 유사활성과 환원력은 대황 에탄올 추출물이 $21.34 \%, 1.710\left(\mathrm{OD}_{700}\right)$ 으로 가장 높았으며, 지방산패억제능 도 대황 에탄올 추출물에서 $83.95 \%$ 로 가장 높았다. 또한, 해조류 추출물의 a-glucosidase 저해 활성은 대황, 감태, 지 충이 열수 추출물에서 $97.75,95.17,87.13 \%$ 를 나타내었으 며, 에탄올 추출물에서는 3종류 모두 약 $98 \%$ 의 높은 저해활 
성을 나타내었다. 해조류 중 대황, 감태, 지충이의 항산화 활성 및 a-glucosidase 저해활성이 우수하여 천연 기능성 소재 개발을 위한 좋은 원료가 될 수 있을 것으로 사료되며, 기능성소재로 사용하기 위하여 적용할 제품에 따라 추출물 의 재료, 첨가농도, 제품의 생리활성 등과 관련된 광범위한 연구가 요구된다.

\section{감사의 글}

본 연구는 산업통상자원부 지정 대구가톨릭대학교 해양 바이오산업연구센터의 지원에 의한 것으로 감사드립니다.

\section{References}

1. Cowburn R, Hardy J, Roberts P, Briggs R (1988) Regional distribution of pre- and postsynaptic glutamatergic function in Alzheimer's disease. Brain Res, 452, 403-407

2. Reiter RJ (1995) Oxidative process and antioxidative defense mechanism in the aging brain. FASEB J, 9, 526-533

3. Cai L, Kang YJ (2001) Oxidative stress and diabetic cardiomyopathy: a brief review. Cardiovasc Toxicol, 1, 181-193

4. Drews G, Krippeit-Drews P, Dufer M (2010) Oxidative stress and beta-cell dysfunction. Pflugers Arch, 460, 703-718

5. Ahn BS, Kim JW, Kim HT, Lee SD, Lee KW (2010) Antioxidant effects of Hovenia dulcis in the streptozotocininduced diabetic rats. J Veterinary Clinics, 27, 366-373

6. Branen AL (1975) Toxicology and biochemistry of butylated hydroxyanisole and butylated hydroxytoluene. J Am Oil Chem Soc, 52, 59-63

7. Mooradian AD, Thurman JE (1999) Drug therapy of postprandial hyperglycaemia. Drugs, 57, 19-29

8. Joo DS, Lee JK, Choi YS, Cho SY, Je YK, Choi JW (2003) Effect of sea tangle oligosaccharide drink on serum and hepatic lipids in rats fed a hyperlipidemic diet. J Korean Soc Food Sci Nutr, 32, 1364-1369

9. Choi IW, Kim SU, Seo DC, Kang BH, Sohn BK, Rim YS, Heo JS, Cho JS (2005) Biosorption of heavy metals biomass of seaweeds, Laminaria species, Ecklonia stolonifera, Gelidium amansii, and Undaria pinnatifida. Korean J Environ Agri, 24, 370-378
10. Oh JK, Shin YO, Sohn HS, Seo RM (2003) Effect of functional food including seaweeds extracts supplementation on hematological variables and antioxidant system. Korean J Physical Education, 42, 895-903

11. Kong CS, Um YR, Lee JI, Kim YA, Lee JS, Seo YW (2008) Inhibition effects of extracts and its solvent fractions isolated from Limonium tetragonum on growth of human cancer cells. Korean J Biotechnol Bioeng, 23, 177-182

12. Lim JH, Jung KS, Lee JS, Jung ES, Kim DK, Kim YS, Kim YW, Park DH (2008) The study on antimicrobial and antifungal activity of the wild seaweeds of Jeju island. J Soc Cosmet Sci Korean, 34, 201-207

13. Cha MH, Kim YK (2008) Analysis of consumption values of a seaweed functional food. Korean J Food Culture, 23, 462-468

14. Lee EH, Ham J, Ahn HR, Kim MC, Kim CY, Pan CH, Um BH, Jung SH (2009) Inhibitory effects of the compounds isolated from Sargassum yezoense on a -glucosidase and oxidative stress. Korean J Pharmacogn, 40, 150-154

15. Folin O, Denis W (1912) On phosphotungsticphosphomolybdic compounds as color reagents. J Biol Chem, 12, 239-249

16. Abdel-Hameed ESS (2008) Total phenolic contents and free radical scavenging activity of certain Egyptian Ficus species leaf samples. Food Chem, 114, 1271-1277

17. Blois MS (1958) Antioxidant determination by the use of a stable free radical. Nature, 181, 1199-1200

18. Re R, Pellegrini N, Proteggente A, Pannala A, Yang M, Rice-Evans C (1999) Antioxidant activity applying an improved ABTS radial cation decolorization assay. Free Radic Biol Med, 26, 1231-1237

19. Marklund S, Marklund G (1974) Involvement of the superoxide anion radical in the autoxidation of pyrogallol and a convenient assay for superoxide dismutase. Eur J Biochem, 47, 469-474

20. Oyaizu M (1986) Studies on products of browning reaction prepared from glucose amine. Jpn J Nutr, 44, 307-315

21. Buege JA, Aust SD (1978) Microsomal lipid peroxidation. Method Enzymol, 52, 302-310

22. Kim KY, Nam KA, Kurihara H, Kim SM (2008) Potent a-glucosidase inhibitors purified from the red alga Grateloupia elliptica. Phytochem, 69, 2820-2825

23. Ahn SM, Hong YK, Kwon GS, Sohn HY (2010) Evaluation of in-vitro anticoagulation activity of 35 
different seaweed extracts. J Life Sci, 20, 1640-1647

24. Middleton E, Kandaswami C (1994) Potential healthpromoting properties of citrus flavonoids. Food Technol, 48, $115-119$

25. Seo YH, Kim IJ, Yie AS, Min HK (1999) Electron donating ability and contents of phenolic compounds, tocopherols and carotenoids in waxy corn (Zea mays L.). Korean J Food Sci Technol, 31, 581-585

26. Nakamura K, Ogasawara Y, Endou K, Fujimori S, Koyama M, Akano H (2010) Phenolic compounds responsible for the superoxide dismutase-like activity in high-brix apple vinegar. J Agric Food Chem, 58, 10124-10132

27. Choudhary RK, Swarnkar PL (2011) Antioxidant activity of phenolic and flavonoid compounds in some medical plants of India. Nat Prod Res, 25, 1101-1109

28. Osawa $T$ (1994) Novel natural antioxidant for utilization in food and biological system. In : Postharvest Biochemistry of Plant Food Material in the Tropics,
Uritani I, Garcia VV, Mendoza EM(editor), Japan Scientific Societies Press, Tokyo, Japan, p 241-251

29. Cojocaru IM, Cojocaru M, Musuroi C, Botezat M, Lazar L, Druta A (2004) Lipid peroxidation and catalase in diabetes mellitus with and without ischemic stroke. Rom J Intern Med, 42, 423-429

30. Lee BB, Park SR, Han CS, Han DY, Park EJ, Park HR, Lee SC (2008) Antioxidant activity and inhibition activity against a-amylase and a-glucosidase of Viola mandshurica extracts. J Korean Soc Food Sci Nutr, 37, 405-409

31. Kim HY, Lim SH, Park YH, Ham HJ, Lee KJ, Park DS, Kim KH, Kim S (2011) Screening of a-amylase, a-glucosidase and lipase inhibitory activity with Gangwon-do wild plants extracts. J Korean Soc Food Sci Nutr, 40, 308-315

32. Xu ML, Wang L, Hu JH, Wang MH (2009) Antioxidant and a-glucosidase inhibitory activities of some wild vegetable extracts. J Agric Food Chem, 47, 4121-4125 